\title{
Target Capital Structure of Egyptian Listed Firms: Importance of Growth and Risk Factors
}

\author{
Aly Saad Mohamed Dawood ${ }^{1} \&$ Mahmoud Otaify ${ }^{2}$ \\ ${ }^{1}$ Sadat Academy for Management Sciences, Faculty of Management seconded to Heliopolis University for \\ Sustainable Development, Faculty of Business and Economics, Egypt \\ ${ }^{2}$ The British University in Egypt, Faculty of Business Administration, Economics and Political Science, Egypt \\ Correspondence: Aly Saad Mohamed Dawood, Sadat Academy for Management Sciences, Faculty of Management \\ seconded to Heliopolis University for Sustainable Development, Faculty of Business and Economics, Egypt.
}

Received: August 29, 2020

Accepted: October 23, 2020

Online Published: December 24, 2020

doi:10.5430/ijfr.v12n1p158

URL: https://doi.org/10.5430/ijfr.v12n1p158

\begin{abstract}
This paper investigates the determinants and adjustment speed to the target capital structure of the Egyptian Listed firms over the period of $2009-2018$. We use panel regression analysis to examine role of growth factors as well as risk factors in explaining the dynamics of target leverage. The main findings of the growth factors model (GFM) reveal that political risk, profitability and stock market return are negatively affect the target leverage of Egyptian firms. In contrast, investment opportunities, non-debt tax shield, firm size have significant positive effect on the target leverage. On the other hand, the results of risk factors model (RFM) indicate that political risk, size and profitability lose their significant effects for the account of firm risk, stock return, investment and asset tangibility. The business risk captures the effect of political risk on the target leverage. Interestingly, both the investment opportunities and the non-debt tax shield preserve their positive effects and thereby they are considered as the most important firm-specific determinants of the target leverage. We find no significant effects of the economic growth, macroeconomic risk and stock market volatility on the target leverage in Egypt. Regarding the adjustment speed and in the presence of growth (risk) factors, the Egyptian firms take 2.7 (4.4) years to adjust their current leverage toward the target leverage.
\end{abstract}

Keywords: adjustment speed, firm-specific risk, stock market volatility, macroeconomic risk, political risk, EGX100 index

\section{Introduction}

Capital structure is defined as mixture of debt and equity used to fund a firm's long-term assets. A number of famous theories provide insights about corporate capital structure decisions, namely, trade-off theory provided by Miller (1977) which argues that managers could trade-off between the tax benefits of debt and the cost of financial distress to select the leverage ratio; signaling theory introduced by Ross (1977) which asserts that managers have superior information about the firm, thereby they could convey information to investors through signals such as increasing (or decreasing) investments, leverage, asset accumulation and share repurchases; pecking order theory suggested by Myers and Majluf (1984) which proposes that firms prefer internal financing to external financing due to factors such as asymmetric information and agency costs. If the internal funds are insufficient, the firms start external financing with debt issuance before resorting to equity financing. Market-timing theory provided by Baker and Wurgler (2002) suggests that firms react to the increase in market share prices by issuing equity. These theories subject to empirical investigation by large numbers of studies to identify determinants of capital structure in different industries and markets. In this regard, it is plausible to examine role of firm characteristics in explaining corporate leverage. So, there is intensive research tends to explore the most significant firm-specific determinants of capital structure (e.g., Devos, et. al., 2012; Belkhir, et. al., 2016; Rashid, 2014; Kent and Kilincarslan, 2018; Shibata and Nishihara, 2018). Other studies attempt to examine the impact of macroeconomic variables on the corporate leverage levels (e.g., Benavente, et. al., 2003; Arena and Roper, 2010; Brei and Charpe, 2012; Li, et. al, 2014; Mokhova and Zinecker, 2014; Groh and Wallmeroth, 2016; Pindado, et. al., 2017; Chow, et. al, 2018; Giombini, et. al, 2018).

Number of studies suggest that firms considerably consider both firm-specific and economic risks when making external financing decisions and debt-equity choices. For example, Bokpin (2010) finds that firm level variables 
such as profitability, investment opportunity, asset tangibility and risk are equally important in predicting firms' capital structure decisions and that economy wide variables such as gross domestic product per capita are significant predictors of financing choices of firms. Lemma and Negash, (2014) find that significant effect of macroeconomic variables; inflation, income level, economic growth as well as that of firm characteristics; bankruptcy, agency costs, transaction costs, access to finance and market timing on capital structure choices of firms in the sample countries. Rashid (2014) argues that firms are more (less) likely to seek external financing when firm-specific (macroeconomic) risk is high. Moreover, the propensity to debt versus equity issues substantially declines in uncertain times, and firms are more likely to pay back their outstanding debt rather than to repurchase existing equity when they face either type of risk. Jackson, et. al. (2013) suggest that debt financing, relative to equity financing, makes managers reluctant to part with assets. In turn, this reluctance (to part with a debt financed asset) causes two decision errors: (1) participants forego investments that increase firm value and (2) participants accept investments that decrease firm value. Bhattacharjee and Han (2014) find important impacts of firm characteristics, macroeconomic instability and institutional factors on the hazard rate of financial distress. Ahsan, et. al. (2016) argue that socio-economic collusive networks, poor corporate governance mechanism along with the weak legal system provide these firms with opportunity to pass on their risk to the creditors.

Many studies attempt to investigate determinants of firms' capital structure in Egypt. Fore example, Youssef and El-ghonamie (2015) try to explore the factors that affect the capital structure of the Egyptian firms working in building materials and construction sector. Sherif, (2015) documents inconsistence in the effects of market timing on leverage over time. The author finds that bankruptcy cost is negatively affecting the leverage ratios of Egyptian listed firms. Recent studies such as El-Habashy (2018) who argues that corporate governance has significant impact on capital structure decisions. Sakr and Bedeir (2019) stipulate that theories of pecking order and trade-off could explain dynamics of capital structure of Egyptian firms but they find weak support for the agency cost theory. Most recently, Alber and Youssef (2020) investigate effect of firm-specific variables, GDP growth, inflation, stock market development on book leverage of firms in Egypt, Turkey, Brazil and Argentina. They find that only profitability is significantly, negatively related to leverage across the four countries. The authors attribute lower leverage level of Egyptian firms to supply (demand) constraints on banking lending (consumer borrowing).

The contribution of current study to literature is threefold. Firstly, it attempts to examine effects of political risk as well as stock market return/volatility on capital structure decisions. Secondly, it compares between role of growth factors and that of risk factors in explaining the dynamics of target leverage using sample firms from emerging country: Egypt. Thirdly, we test whether the adjustment speed differs according to the type of factors - either growth or risk related. In doing so, we estimate two main models: Growth Factors model (GFM) and Risk Factors Model (RFM) to measure the target leverage for each firm and then calculate adjustment speed for each model.

This paper organized as follow: section 2 introduces main studies have been investigated the determinants of adjustment speed of capital structure, section 3 presents methodology applied while section 4 describes data and variables included. Section 4 displays both specification and estimation results of different econometric models. Finally, section 5 presents discussion and conclusion.

\section{Literature Review}

Theories of pecking order and market timing suggest views about capital structure decision. However, they do not assume thought regarding target leverage (Note 1) and adjustment toward the target Dang, et. al, (2012). Nevertheless, the trade-off theory implies that firms' capital structures are mean reverting towards the target structure. In other words, the trade-off theory assumes that in the presence of market imperfections, capital structure (leverage) decisions have effect on firm value Devos, et. al, (2017). Thus, it is expected that target (optimal) leverage ratio maximizes the firm value and thereby the firms should continuously adjust their deviations from the target leverage. As a result, many studies have investigated empirically the validity of trade-off theory by testing the speed at which firms adjust their leverage ratio towards their target leverage.

Chan and Chang (2008) support the trade-off theory and documents significant effect of stock return shocks on adjustment towards the target leverage. Lemma and Negash (2014) find that firms in developing countries do temporarily deviate from (and partially adjust to) their target capital structures. Moreover, they indicated that more profitable firms tend to rapidly adjust their capital structures than less profitable firms, the adjustment speed differs based on measure of capital structure and tends to be faster for firms in industries with relatively higher risk and countries with common law tradition, less developed stock markets, lower income, and weaker creditor rights protection. Kim, et. al (2015) apply dynamic partial adjustment model to estimate the adjustment speeds toward targets based on economic conditions using Korean data. They find that during economic expansion periods, firms 
tend to adjust their debt financing faster toward target ratio. Rashid (2014) estimates adjustment speeds and indicates that both firm-specific risk and macroeconomic risk significantly affect the speed at which firms adjust their capital structure toward the target and shows that firms adjust their leverage faster toward the target when firm-specific risk is relatively low.

Belkhir, et. al. (2016) document asymmetric speed across firms in MENA region in adjusting their capital structures. Baum, et. al, (2017) document that adjustment process is asymmetric and depends on the type of risk, its magnitude, the firm's current leverage, and its financial status. They reveal that firms with financial surpluses and above-target leverage adjust their leverage more rapidly when firm-specific risk is low and when macroeconomic risk is high while firms with financial deficits and below-target leverage adjust their capital structure more quickly when both types of risks are low. Karpavičius and Yu (2017) suggest that firms do not adjust their capital structures based on interest rates, except when market participants have negative real gross domestic product growth.

In a perfect capital market, firms adjust instantaneously their capital structures for the target and in turn there is no adjustment cost (Faulkender et al., 2006; Flannery and Hankins, 2013). However, market imperfections such as asymmetric information and transaction costs lead to deviations from the target leverage Hüttel, et. al, (2010). In turn, the adjustment speed towards target leverage is affected by the cost of adjustment as well as the cost of deviation. That is, adjustment speed tends to be faster when cost of adjustment is low or/and cost of deviating from the target is high (Fischer, et. al, 1989; Flannery and Rangan, 2006). Table 1 presents a summary for studies reported adjustment speed of the actual leverage towards the target one.

Table 1. Summary of selected studies for adjustment speed of leverage

\begin{tabular}{lllc}
\hline \multicolumn{1}{c}{ Study } & \multicolumn{1}{c}{ Sample } & \multicolumn{1}{c}{ Period } & $\begin{array}{c}\text { Adjustment } \\
\text { Speed* }\end{array}$ \\
\hline Fama and French (2002) & 300 firms & $1965-1999$ & $15 \%$ \\
\hline Flannery and Rangan, 2006) & 12,919 firms & $1965-2001$ & $33 \%$ \\
\hline Chan and Chang (2008) & 122 Taiwan firms & $1995-2003$ & $69.7 \%-83.47 \%$ \\
\hline Aybar-Arias, et, al, (2012) & 947 SMEs Spanish firms & $1995-2005$ & $26 \%$ \\
\hline $\begin{array}{l}\text { Drobetz, Schilling and Schröder } \\
\text { (2015) }\end{array}$ & 10,772 firms from G7 countries & $1992-2011$ & $25 \%$ per year \\
\hline Lemma and Negash (2014) & $\begin{array}{l}\text { 986 firms drawn from nine African } \\
\text { countries }\end{array}$ & $1999-2008$ & $39.4 \%-59 \%$ \\
\hline Kim, et. al, (2015) & Korean non-financial firms & $1990-2010$ & $34.8 \%-50.7 \%$ \\
\hline Soekarno, et. al, (2016) & 14 Indonesian state-owned enterprises & $1995-2013$ & $45.65 \%$ \\
\hline Ghose (2017) & 1,415 listed Indian manufacturing firms & $2005-2013$ & $30 \%$ \\
\hline Kythreotis, et. al, (2017) & $\begin{array}{l}\text { 178 Iranian companies and } \\
\text { 187 Australian companies }\end{array}$ & $2009-2015$ & $91 \%$ and 92\% \\
\hline Aderajew, et. al, (2019) & panel of 1,500 Dutch farms & $2001-2015$ & $11.38 \%-64 \%$ \\
\hline
\end{tabular}

*As \% of the Gap between actual and Target Leverage

However, to our best knowledge, there is a scarcity in empirical studies focusing on the adjustment speed towards target leverage using Egyptian data and the current paper attempts to cover this research gap accordingly. The basic hypothesis of current study is that managers respond asymmetrically to growth factors and risk factors in targeting their capital structure. (Note 2) Consequently, the speed of adjusting their current leverage ratio towards the target leverage differs according to the factors (growth or risk) considered. In the following paragraphs, we develop research hypotheses about the expected relations between each variable and target leverage. Starting with firm growth, when the low-growth firms are mature and have stable profits, they tend to use debt financing to avoid the free cash flow problem Jensen, (1986). Due to the cost of asymmetric information, firms tend to increase debt 
(leverage) after utilizing the internal funds when they have favorable growth projections Aybar-Arias, et, al, (2012). Thus, we expect that There is a significant impact of Firm growth on Target Leverage (H1).

As volatility of total sales (as a proxy for firm-specific risk) increases, the risk the firms would not be able to satisfy debt obligations Barry, et. al, (2000). This entails a negative relation between business risk and leverage which is supported by the trade-off theory because the higher business risk, the higher probability of bankruptcy risk Burgman, (1996). Conversely, signaling theory proposes that firms may seek to raise debt ratio as a signal of favorable expected future earnings Flannery and Rangan, (2006). Thus, signaling theory suggests positive impact of business risk on leverage. Thus, we expect that there is a significant impact of Firm risk on Target Leverage (H2).

Some studies investigate role of stock market in explaining financing decisions of listed firms. For example, Kunt and Maksimovic (1996) report that initial improvement in the stock market development is associated with more leverage but the improvements in already developed markets result in more equity issuance. Agarwal and Mohtadi (2004) suggest that equity market development favors firms' equity financing over debt financing, while banking sector development favors debt financing over equity financing. Moreover, Bokpin (2010) documents that the significant impact of the financial market development and macroeconomic variables on capital structure vary with the maturities of the security issue. Recently, Tai (2017) find the stock market capitalization has a positive effect on capital structure while market liquidity has a negative effect on the capital structure. To our best knowledge, effect of both stock market return and volatility has low focus in literature, thus, we examine their effect on target leverage. In turn, we predict the following hypotheses:

\section{H3: There is a significant impact of Stock Market Return on Target Leverage.}

\section{H4: There is a significant impact of Stock Market Volatility on Target Leverage.}

It is well documented that real economic growth is associated with investment opportunities because valuable investment opportunities would result in economic growth. Alternatively, high economic growth involves less risk and hence investors would require lower rate of return and more projects become visible Kelly, et. al, (2003). Moreover, firms with large profits associated with economic growth induce firms to depend on internal sources of finance more than using external sources which supports the pecking order theory Mokhova and Zinecke, (2014). Recent empirical studies such as Mai, et. al, (2017) find that growth rate of GDP is positively impacting firm leverage which indicates that firms tend to borrow debt $\mathrm{n}$ periods of economic booms. Therefore, we expect that there is a significant impact of Macroeconomic Growth on Target Leverage (H5).

On the other hand, Schwert (1989) explained the relationship between level of economic activity and stock market volatility because of financial leverage. Since stock prices (as a leading indicator) could predict economic activity, they decrease before and during recession which would increase leverage and consequently increase volatility of leveraged stocks. Similarly, firms with high operating leverage (large, fixed costs) would face a drop in net profits in recession periods due to decline in demand. Thus, their stock prices decrease and volatility increases during the recession. Thus, we expect that there is a significant impact of Macroeconomic risk on Target Leverage (H6).

Regarding the effect of political uncertainty, firms tend to use more (less) debts when they expect low (high) political uncertainty Cashman, et. al, (2015). It is expected that political uncertainty increases cost of debt Wang, et. al, (2019) and consequently depress demand for debt and leverage ratios decrease accordingly. Pan, et. al, (2019) reveal that political uncertainty affects negatively both the debt maturity and leverage, especially for firms with greater investment reversibility and a lower credit Rating. In contrast, Amelot, et. al, (2018) report insignificant effect of political risk on Mauritius firms' leverage decision. We expect that there is a significant impact of Political Risk on Target Leverage (H7).

Large firms have several benefits include, they face lower cost of asymmetric information Frank and Goyal, (2009), argue that diversified business activities due to firm size have less volatility of cash flows that lower possibility of financial distress. Graham, et. al, 2015), find that large investments increase firms bargaining power to access financial market. Rajan and Zingales, (1995) as a result, larger (smaller) firms could get loans at lower (higher) cost which implies a positive impact of firm size on leverage. We expect that there is a significant impact of Firm Size on Target Leverage (H8).

According to pecking order theory, High (low) profitable firms are more (less) likely to have sufficient (insufficient) internal source of funding - retained earnings generated from firm business activity to finance growth opportunities. Moreover, the greater (lower) financial flexibility and strength allow the high (low) profitable firms from issuing securities at lower (higher) cost. Both benefits are in favor of prediction of negative relation between profitability and leverage ratio. On the other hand, the high (low) profitable firms are encouraged (depressed) to take the 
advantage of tax savings associated with debt financing and to decrease (increase) the asset substitution effect, especially when they have low (high) debt ratio. This implies a positive impact of profitability on leverage. Furthermore, the signaling theory also assumes a positive relationship because lenders are more (less) willing to lend to high (low) profitable farms Featherstone et al., (2005). We expect negative relation between profitability and leverage. Thus, we predict that there is a significant impact of Firm Profitability on Target Leverage (H9).

The higher (lower) capital expenditures of a firm are considered as a good (bad) signal for the expected future cash flows and hence they could take loans at favorable (adverse) conditions Zhao, et. al, (2008). This implies a positive impact firm of investments on leverage. Therefore, we expect that there is a significant impact of Firm Investment on Target Leverage (H10).

Higher tangibility of fixed assets results in lower probability of the financial distress bearing lower cost accordingly because they could be used as collateral for debts and Hovakimian, et. al, (2004). Consistently, Kim, et. al, (2015) claim that firms with more tangible assets are more recognizable to the lenders and consequently cost of asymmetric information should be lower. Moreover, authors assume that theories of pecking order and signaling predict a positive impact of asset tangibility on leverage. We predict that there is a significant impact of Firm Asset Tangibility on Target Leverage (HII).

The agency theory predicts negative relation between investment opportunities and leverage because shareholders are induced to underinvest Myers, (1977). Consistently, the trade-off theory assumes that these investment opportunities as intangible assets cannot be collateralized Sheikh and Wang, (2011) and hence managers have less incentive to borrow to fund these opportunities. Conversely, the pecking order theory predict positive relation between investment opportunities and leverage because of the asymmetric information between insiders and outsiders increases cost of equity financing and encourage managers to raise debts accordingly Sakr and Bedeir, (2019). Lagged value has been utilized of market value of equity to book value of equity (MTB) ratio because it is more informative about investment opportunities than the current ratio which tend to represent market misevaluation or temporary fluctuations Baker and Wurgler, (2002). Thus, we expect that there is a significant impact of Firm investment Opportunities on Target Leverage (H12). Since depreciation expense is not actual cash outflow, firms with higher depreciation expenses are likely to have less leverage to enjoy the tax-shield with lower risk of financial distress Kim, et. al, (2015). Therefore, we predict that there is a significant impact of Firm Non-Debt Tax Shield on Target Leverage (H13).

According to market timing theory suggested by Baker and Wurgler (2002), firms react to increase (decrease) in their market share prices (proxied by market-to-book (MTB) ratio) by issuing (repurchasing) equity. Conversely, Frank and Goyal (2004) find no evidence on equity issuance in response to high MTB ratio but they document a reduction in debt. Yang, (2013) documents that changes in investor beliefs have significant impact on corporate leverage, that is good investor belief (higher stock price) would result in decrease in leverage. This implies negative relation between stock returns and leverage. Recently, Seo and Chung (2017) examine corporate reactions to drop in its stock price. They find that firms prefer repurchases stocks to support share prices (because of negative share price shocks) to repay debt. Regarding volatility, Ahmed and Hla (2018) find that firms tend to adjust their leverage downwardly in response to the increase in stock return volatility as well as to minimize the default risk. Thus, we expect that there is a significant impact of Firm stock return on Target Leverage (H14).

\section{Data}

We use a firm-level balanced annual panel dataset for 77 non-financial firms listed on Egyptian broad index; EGX100 which represents different sectors in the Egyptian stock exchange over the period 2009 - 2018. Data for the firm-specific variables are obtained from Thomson Reuters database while for macroeconomic data are attained from central bank of Egypt. Stock market return are available on the official website of the Egyptian stock exchange while data about political risk are obtained from the Worldwide Governance Indicators (WGI). On the side of independent variables, we use number of firm specific characteristics including firm size, asset tangibility, profitability, the 2-year stock return, market-to-book value (MTB) ratio, non-debt tax shield, corporate investment. We use growth of sales as a proxy for firm growth and growth rate of real gross domestic product (GDP) as proxy for economic growth.

We follow the most recent studies in using the book leverage instead of market leverage. Baum, et. al, (2017) justify this choice for three reasons; (1) regarless of actual debt ratio, as marker share price in stock market changes, market leverage will change; (2) financial institutions use book value of debt to assess firm's creditwothiness in order for granting new debt; (3) credit-rating for firms is based on their book value of debt. Book leverage has been measured as the ratio of book debt to total assets where book debt is the difference between total assets and book equity. Book 
equity is total assets minus total liabilities and preferred stock plus deferred taxes and convertible debt (Baker and Wurgler, 2002 and Kayhan and Titman, 2007). Detailed measurement for each variable is shown in table (2).

Table 2. List of variables and their measurement

\begin{tabular}{|c|c|}
\hline Variable & Measurement \\
\hline \multicolumn{2}{|l|}{ Dependent Variable } \\
\hline Book leverage & $\begin{array}{l}\text { The ratio of book debt to total assets. Book equity is total assets minus total } \\
\text { liabilities and preferred stock plus deferred taxes and convertible debt. Book debt is } \\
\text { Total assets minus book Equity }\end{array}$ \\
\hline \multicolumn{2}{|l|}{ Growth and Risk Factors } \\
\hline Business Growth & Growth of total sales \\
\hline Business Risk & Volatility of sales \\
\hline Real GDP & $\begin{array}{l}\text { Average of four quarters where each is equal one plus the change percentage of } \\
\text { GDP divided by one plus inflation rate for the same period and all minus } 1\end{array}$ \\
\hline Stock market return & Average of daily EGX100 natural logarithm of relative numbers \\
\hline Political Risk & The Worldwide Governance Indicators (WGI) estimation \\
\hline \multicolumn{2}{|l|}{ Control Variables } \\
\hline Size & The logarithm of net sales \\
\hline Profitability & $\begin{array}{l}\text { The ratio of earnings before interest, taxes, and depreciation to the book value of } \\
\text { total assets. }\end{array}$ \\
\hline Investment & capital investment expenditures \\
\hline Non-debt tax shield & Total depreciation expense divided by the book value of total assets \\
\hline 2-year stock total return & $\begin{array}{l}\text { The percentage change between share prices at time } \mathrm{t}-2 \text { and share prices at time } \mathrm{t} \\
\text { and any dividends over the period two years. }\end{array}$ \\
\hline $\begin{array}{l}\text { Market To Book equity value } \\
\text { (MTB) }\end{array}$ & market value divided by book equity \\
\hline
\end{tabular}

\section{Econometric Models}

To determine the impact of the independent variables on the book leverage and, the pooled OLS model, the fixed effects model and the random effects model are the most common static linear panel data analysis models are used. In short, Pooled OLS does not distinguish between firm effects while also neglecting the cross section and time series nature of the data. However, fixed effects model allows each firm to have its own intercept, but it is remaining the same over time. Finally, in the random effects model, there is no correlation between the firm specific effects and the independent variables, and the firm effects are parameterized as additional random error term.

\subsection{Growth Factors Model Specification}

A growth factors model (GFM) seeks to estimate impact of macroeconomic growth, firm growth opportunities, stock market return in addition to political risk in the presence of firm characteristics as control variables on adjustment speed of firms' capital structure. To do so, we apply panel regression analysis to estimate firstly the firm's target debt ratio and secondly estimate the firm's adjustment speed.

In a frictionless economy, the actual (observed) leverage of firm $i$ at time $t$, should be the target leverage. (Note 3) In turn, we estimate the target leverage ratio of the firm, $L_{i, t}^{T}$, using the following equation:

$$
L_{i, t}^{T}=\beta_{1} X_{i, t-1}+\beta_{2} G_{i, t-1}^{\text {Firm }}+\beta_{3} G_{t-1}^{\text {Market }}+\beta_{4} G_{t-1}^{\text {Econ }}+\beta_{5} R_{t-1}^{\text {Pol }}+\varphi_{i}+\varepsilon_{i}
$$

Where $X_{i, t}$ a vector of firm characteristics variables is: lagged values of book value, size, profitability, non-debt tax shields, M/B ratio, asset tangibility, capital expenditures, 2 -year stock return. Terms $G_{i, t}^{\text {Firm }}, G_{t}^{\text {Market }}$, $G_{t}^{\text {Econ }}$ denote firm growth of sales (measured by ratio of sales to total assets), stock market return (measured by change in 
EGX100 index) and economic growth (measured by growth rate of real GDP), respectively. $R_{i, t}^{\text {Pol }}$ denotes political risk. $\varphi_{i}$ captures time-invariant unobservable firm-specific fixed effects while $\varepsilon_{i}$ is the idiosyncratic error term.

Give the target leverage, firm adjust their current leverage at certain speed towards the target leverage, depending on the trade-off between cost of deviating from the target leverage and cost of adjusting the current ratio towards the target (Leary and Roberts, 2005). Using the target leverage of firm from eq. (1), we can estimate the adjustment speed towards the target utilizing the following equation:

$$
L_{i, t}-L_{i, t-1}=\gamma\left(L_{i, t}^{T}-L_{i, t-1}\right)+\varepsilon_{i}
$$

Where $L_{i, t}$ is the actual debt ratio (leverage) of firm $i$ in year $t$. The lagged value of leverage, $L_{i, t-1}$, is included to build a dynamic specification for considering potential effect of the autoregressive process and costs of adjustment (Byoun, 2008). The $\gamma$ coefficient measures adjustment speed of firm's capital structure towards the target leverage. In other words, it works as a convergence rate of current leverage to the target leverage. Moreover, it should take value between zero and one in case of positive adjustment costs. A large value of $(\gamma)$ coefficient implies faster adjustment speed which is related positively with the difference between the deviation cost from the target and the adjustment cost. In short, the change in leverage depends on adjustment speed and the distance between lagged leverage and the target leverage.

\subsection{Estimation Results of Growth Factors Model (GFM)}

Table 3 presents the results of estimating the common three linear panel data analysis models (the pooled OLS model, the fixed effects model and the random effects model) for equation (1) to analyze the activity effect of firm-business, stock market, growth of real GDP, political risk and control variables on target book leverage, $D_{i, t}^{T}$.

Table 3. Pooled OLS, fixed effects and random effects models

\begin{tabular}{|c|c|c|c|}
\hline Var. & Pooled OLS & Fixed Model & Random Model \\
\hline \multicolumn{4}{|c|}{ Dependent Variable: Target book leverage } \\
\hline \multicolumn{4}{|c|}{ Total Observations: 77 firms $\times 10$ periods $=770$ observations. } \\
\hline$L_{i, t-1}$ & $1.113^{* * *}$ & $1.077^{* * *}$ & $1.111^{* * *}$ \\
\hline Asset Tangibility $_{i, t-1}$ & $-0.032 * * *$ & -0.003 & -0.033 \\
\hline Size $_{i, t-1}$ & $-0.012 * * *$ & $0.140^{* *}$ & -0.005 \\
\hline Profitability $_{i, t-1}$ & $-0.199 * * *$ & $-0.293 * * *$ & $-0.210 * * *$ \\
\hline Investment $_{i, t-1}$ & $6.65 \mathrm{E}-06 * *$ & $1.17 \mathrm{E}-06$ & $5.08 \mathrm{E}-06$ \\
\hline Non - Debt Tax Shield ${ }_{i, t-1}$ & $0.134 * * *$ & $0.105^{* * *}$ & $0.123^{* * *}$ \\
\hline \multicolumn{4}{|l|}{ Ytd Total Return $_{i, t-1}$} \\
\hline & $-0.001 * *$ & -0.00031 & -0.001 \\
\hline$M T B_{i, t-1}$ & $1.96 \mathrm{E}-06^{* * *}$ & $1.75 \mathrm{E}-06^{* * *}$ & $1.95 \mathrm{E}-06^{* * *}$ \\
\hline$G_{i, t-1}^{F i r m}$ & $-7.48 \mathrm{E}-07$ & $-2.31 \mathrm{E}-06$ & $-1.10 \mathrm{E}-06$ \\
\hline$G_{t-1}^{E c o n}$ & $-0.052 * * *$ & -0.073 & -0.051 \\
\hline$G_{t-1}^{\text {Market }}$ & -0.006 & $-0.033^{*}$ & -0.006 \\
\hline$R_{t-1}^{P o l}$ & $-0.049 * * *$ & $-0.043^{*}$ & $-0.048 * *$ \\
\hline $\mathrm{C}$ & -0.051 & $-0.451 * * *$ & -0.065 \\
\hline Adjusted R-squared & 0.889 & 0.898 & 0.858 \\
\hline Akaike inf criterion & -1.124 & -1.065 & --- \\
\hline Schwarz inf criterion & -1.112 & -0.407 & --- \\
\hline Hannan-Quinn criter. & -1.120 & -0.809 & --- \\
\hline
\end{tabular}

***denotes significant at $1 \%, * *$ denotes significant at $5 \%$ and $*$ denotes significant at $10 \%$. 
The coefficient of lagged book leverage is positive and statistically significant. It is recorded also that the coefficients of size (H8), MTB ratio (H12) and non-debt tax shield (H13) factors are positive and statistically significant. The positive impact of size on leverage supports the trade-off theory. Larger firms are more diversified and consequently have less possibility of financial distress and have less cost of asymmetric information and could borrow at favorable terms accordingly. This result is in the line of Ghose (2017) and Mai, et. al, (2017) while it contradicts with Soekarno, et. al, (2016), Dufour, et. al, (2018), Kythreotis, et. al, (2018). With respect to previous studies on Egypt, this result is consistent with those of El-Habashy (2018), Sakr and Bedeir (2019).

MTB ratio is positively impacting leverage which is consistent with the pecking order theory. Firms with higher growth opportunities tend to borrow debts to fund these investments. Moreover, this implies that investment opportunities are sufficiently guarantee the financial obligations of debt repayments. This result is in line with Ghose (2017) but it contradicts with Mai, et. al, (2017). The positive impact of non-debt tax shield on leverage indicates that tax benefits achieved from depreciating assets are not enough for the firms which are more likely to borrow more debts. On the other hand, firms with high non-debt tax shield indicates that leverage ratio is low and hence they have opportunity to lever up their operations. This finding contradicts with those of Soekarno, et. al, (2016) and Flannery and Rangan (2006). In contrast, the coefficients of political risk, profitability and stock market return are negative and statistically significant. These results confirm the research hypotheses; H3, H7 and H9. Stock market return is negatively impacting target leverage, that is, the increase in prices of most stocks encompassed in the index is associated with a decrease in debt. This implies that Egyptian firms exploit this increase as an indicator of high investor sentiment in holding stocks to issue equity at high prices and thereby reduce leverage ratio. Moreover, this interpretation complies with the prediction of market timing theory.

Regarding the political risk, Egyptian firms tend to raise debt in periods of low political uncertainty. This result agrees with those of Cashman, et. al, (2015) and Cashman (2016). The negative impact of profitability on target leverage supports the pecking order theory, that is, more profitable firms need less external funding and thus ask less debt financing. This result is in accord with those of Mai, et. al, (2017), Ghose (2017), Dufour, et. al, (2018), Kythreotis, et. al, (2018), Aderajew, et. al, (2018). Conversely, this result is not in accord with those of Sakr and Bedeir (2019). The study does not find strong evidence for: firm (business) growth (H1), firm investment (H5), economic growth (H10), asset tangibility (H11) and 2 YTD Total Return (H14). The insignificant coefficients of business growth and economic growth indicate that growth factors have weak explanatory power in explaining the dynamics of target leverage ratio.

\subsection{Estimation Results of Adjustment Speed Model}

Table 4. Capital structure adjustment speed for the growth factor model

\begin{tabular}{ccc}
\hline Dependent Variable: $\mathrm{L}_{i, t}-L_{i, t-1}$ & & \\
\hline Variable & coefficient & Sig. \\
\hline$L_{i, t}^{T}-L_{i, t-1}$ & 0.3648 & 0.000
\end{tabular}

It is observant that the adjustment coefficient is positively statistically significant and equals $36.48 \%$ which indicates that the cost of deviating from the target is higher than the cost of adjustment and so that the speed of adjustment will be faster and according to the nature of data processed it indicate that the higher the stability of variable figures the faster the adjustment, in other words the higher the stability of significant variables the faster the adjustment speed. The coefficient value of adjustment speed is between zero and one which indicates that firm's leverage ratio converges to its target leverage over time. Moreover, this indicates that capital structure decisions of Egyptian firms tend to be dynamic. Typically, the value of $\gamma$ coefficient is usually expressed in terms of the time needed to move to the target capital structure after a shock. Therefore, the Egyptian firms close 36.5 percent of the gap between the current leverage ratio and the target ratio in one year, that is, they take about 2.74 year (100 percent divided by 36.5 percent) to move to their target leverage, i.e., to cover $100 \%$ of gap between the current and the target leverage ratios. This speed exceed that reported by Lemma and Negash (2014) when the sample firms (including Egyptian firms) take less than two years to move to their optimal short-term leverage, long-term leverage, and total leverage. Consistent with study of Aybar-Arias, et, al, (2012) who find that Spanish SME close 26\% of the gap which is equivalent to take 2.5 years to reach the target leverage. In contrast to findings of Aderajew, et. al, (2018) who report adjustment speed of farm ranging from $11.38 \%$ - 64\% which indicates that the adjustment speed of Dutch farms is 
slow. Collectively, managers of Egyptian firms take 2.74 years to adjust the current leverage towards the target leverage in response of changes size, MTB ratio, non-debt tax shield, political risk, profitability and stock market return.

\subsection{Risk Effect Model Specification}

We follow methodology of Baum et. al. (2017) in measuring business risk using the autoregressive model as well as in measuring macroeconomic risk using ARCH model.

\subsubsection{Measuring Business Risk}

We measure the volatility of net sales-to-assets as a proxy of business risk (or firm-specific risk) using an autoregressive model.

$$
\text { Sales }_{i, t}=\mu_{i}+\varphi \text { Sales }_{i, t-1}+\xi_{i, t}
$$

Where Sales $_{i, t}$ is the ratio of sales to total assets for firm i at time t, $\mu_{\mathrm{i}}$ captures the fixed effects, $\phi$ is the autoregressive parameter, and $\varepsilon_{i, t}$ is the error term. Technically, we estimate equation (3) for each firm, then calculate the variance of the residuals obtained. Finally, the square root of these estimated variance will be used as a proxy for business risk and denoted as $R_{i, t}^{F i r m}$ in estimation of Risk factors Model (RFM).

\subsubsection{Measuring Macroeconomic Risk}

We apply ARCH model on quarterly real GDP series to generate series of conditional variance of real GDP as a proxy of macroeconomic risk. The ARCH model consists of two equations: mean equation and variance equation as follow:

$$
\begin{gathered}
G_{t}^{E c o n}=\omega+\theta G_{t-1}^{E c o n}+\varepsilon_{t} \\
\sigma_{t}^{2}=\alpha+\beta \varepsilon_{t-1}^{2}
\end{gathered}
$$

Where $\omega$ and $\theta$ are the constant term and autoregressive parameter, respectively. We the estimated value of the conditional variance, $\sigma_{t}^{2}$ is averaged over four quarters to generate annual variance of real GDP as a proxy of macroeconomic risk denoted by $R_{t}^{\text {Macro }}$ which then used in the estimation of Risk Factors Model (RFM). Table (5) reports results of estimating ARCH model for quarterly growth rate of real GDP. Most importantly, the ARCH effect is statistically significant at $1 \%$ and its value less than $1(\beta=\mathbf{0 . 1 8 0 9 5})$ which implies volatility shock is less persistent.

Table 5. ARCH model estimates for macroeconomic risk

\begin{tabular}{ccc}
\hline & Coefficients & Sig. \\
\hline$G_{t-1}^{E c o n}$ & $\mathbf{- 0 . 1 0 9 5 7 ^ { * * * }}$ & $\mathbf{0 . 0 0 7}$ \\
\hline Constant & $\mathbf{- 0 . 0 0 0 8 4}$ & $\mathbf{0 . 1 4 5}$ \\
\hline AR(1) & $\mathbf{- 1 . 2 0 5 5 9 * *}$ & $\mathbf{0 . 0 0 0}$ \\
\hline ARCH(1) & $\mathbf{- 0 . 1 8 0 9 5 * *}$ & $\mathbf{0 . 0 0 2 9 4}$ \\
\hline Constant & $\mathbf{0 . 0 0 7 7 * *}$ & $\mathbf{0 . 0 3 1 5}$ \\
\hline & Tests for remaining ARCH effects & $\mathbf{0 . 0 6 4 4}$ \\
\hline LM-test(4) & $\mathbf{2 . 5 2 0 9 6}$ & $\mathbf{0 . 1 2 8 9}$ \\
\hline LM-test( $(8)$ & $\mathbf{1 . 8 5 1 8}$ & $\mathbf{0 . 1 1 5}$ \\
\hline $\mathrm{Q}(4)$ & $\mathbf{7 . 4 3 7}$ & $\mathbf{0 . 1 4 3}$ \\
\hline $\mathrm{Q}(8)$ & $\mathbf{1 2 . 0 5}$ &
\end{tabular}

**denotes significant at $1 \%$, and $*$ denotes significant at $5 \%$.

\subsubsection{Measuring Stock Market Volatility}

We use ARCH model for generating a proxy for stock market volatility (risk) as follow:

$$
G_{t}^{\text {Market }}=\omega+\theta G_{t-1}^{\text {Market }}+\varepsilon_{t}
$$




$$
\sigma_{t}^{2}=\alpha+\beta \varepsilon_{t-1}^{2}
$$

Where $G_{t}^{\text {Market }}$ is change in EGX100 index at year $\mathrm{t}$ as measure of stock market return. As mentioned before, we takes the estimated conational variance series and use it as a proxy of stock market risk denoted by $R_{t}^{M a r k e t}$ in the estimation of RFM. Table 6 indicates that ARCH effect is significant at $1 \%$ and its value less than one $(\beta=\mathbf{0 . 3 4 9 9})$.

Table 6. ARCH model estimates for stock market volatility

\begin{tabular}{ccc}
\hline & Coefficients & Sig. \\
\hline$G_{t-1}^{\text {Market }}$ & $\mathbf{- . 9 9 8 3 * *}$ & $\mathbf{0 . 0 0 0}$ \\
\hline Constant & $\mathbf{- 0 . 0 0 0 0 3 0 6}$ & $\mathbf{0 . 2 9 1 3}$ \\
\hline AR(1) & $\mathbf{0 . 1 9 6 2 2 * *}$ & $\mathbf{0 . 0 0 0}$ \\
\hline MA(1) & $\mathbf{0 . 0 4 4 1 2 * *}$ & $\mathbf{0 . 0 0 0}$ \\
\hline MA(2) & $\mathbf{- 0 . 9 5 4 0 3 * *}$ & $\mathbf{0 . 0 0 0}$ \\
\hline ARCH(1) & $\mathbf{0 . 3 4 9 9 * *}$ & $\mathbf{0 . 0 0 0}$ \\
\hline Constant & $\mathbf{0 . 0 0 0 1 3 4 * *}$ & $\mathbf{0 . 0 0 0}$ \\
\hline TM-test $(4)$ & Ther remaining ARCH effects & $\mathbf{0 . 5 0 9 2 5}$ \\
\hline L-test $(8)$ & $\mathbf{0 . 8 4 8 5}$ & $\mathbf{0 . 7 2 9 0}$ \\
\hline Q $(8)$ & $\mathbf{2 . 6 6 4 9}$ & $\mathbf{0 . 5 5 9 7}$ \\
\hline
\end{tabular}

$* *$ denotes significant at $1 \%$ and $* *$ denotes significant at $5 \%$.

The results presented in Tables $5 \& 6$ reveal the suitability of ARCH model to capture the volatility of the behavior of the macroeconomic risk and stock market volatility. As, the diagnostics tests, Lagrange multiplier (ARCH-LM) test and Q-statistics, are all non-significant. Additionally, the ARCH coefficients are less than one and are statistically significant. These results are consistent with the empirical findings of Baum, et. al, (2017) for encourage us to use ARCH model for generating a proxy for both macroeconomic risk as well as stock market.

\subsubsection{Risk Factors Model Specification}

A risk factors model (RFM) aims at analyzing the risk effects of macroeconomic, firm growth opportunities, stock market in addition to political risk and in the presence of firm characteristics as control variables on the adjustment speed of firms' capital structure. In doing so, we replace growth factors variables equation (1) with risk factors variables as shown in equation (8).

We re-estimate the target debt ratio of the firm, $L_{i, t}^{T}$, using the following equation:

$$
L_{i, t}^{T}=\beta_{1} X_{i, t-1}+\beta_{2} R_{i, t-1}^{\text {Firm }}+\beta_{3} R_{t-1}^{\text {Market }}+\beta_{4} R_{t-1}^{\text {Macro }}+\beta_{5} R_{t-1}^{\text {Pol }}+\varphi_{i}+\varepsilon_{i}
$$

Where $R_{i, t}^{\text {Firm }}$ denotes firm-specific risk (business risk) while $R_{t}^{\text {Market }}, R_{t}^{\text {Macro }}$ denote to the stock market risk (volatility) and macroeconomic risk, respectively. Then, we re-estimate the firm's adjustment speed using equation (2).

\subsubsection{Estimation Results of Risk Effect Model}

Table 7 shows results of RFM using both fixed effect and random effect models. It is recorded that the coefficients of investment, MTB, non-debt tax shield factors are positive and statistically significant. Thus, these findings accept H10, H12 and H13 hypotheses. The results indicate that firms with larger capital expenditures tend to increase leverage because they expect larger future cash flows that able to satisfy the debt obligations. This supports the signaling theory. This result complies with Aderajew, et. al, (2018). Positive impact of MTB on leverage supports the prediction of the trade-off theory that lagged MTB is more informative than the current MTB ratio about the investment opportunities. Accordingly, firms with high investment opportunities tend to raise debt. This result is consistent with those of Sakr and Bedeir (2019). The positive impact of the non-debt tax shields on leverage contradicts the prediction of the trade-off theory. Accordingly, they have opportunity to raise leverage to finance 
their investments. This result contradicts those of El-Habashy (2018). In contrast, the coefficients of firm-specific (business) risk (H2), Asset tangibility (H11) and 2 YTD Total Return (H14) are negative and statistically significant.

Table 7. Fixed effects and random effects models

\begin{tabular}{|c|c|c|}
\hline Var. & Fixed Model & Random Model \\
\hline \multicolumn{3}{|c|}{ Dependent Variable: Target book leverage, $L_{i, t}^{T}$} \\
\hline \multicolumn{3}{|c|}{ Total Observations: 77 firms $\times 10$ periods $=770$ observations. } \\
\hline$L_{i, t-1}$ & $1.0758 * *$ & $1.111 * *$ \\
\hline Asset Tangibility $_{i, t-1}$ & 0.0056 & $-0.03460 * *$ \\
\hline Size $_{i, t-1}$ & $0.13044 * *$ & -0.01555 \\
\hline Profitability $_{i, t-1}$ & $-0.30645^{* *}$ & -0.20398 \\
\hline Investment $_{i, t-1}$ & $-1.2 \mathrm{E}-06$ & $6.86 \mathrm{E}-06 *$ \\
\hline Non - Debt Tax Shield ${ }_{i, t-1}$ & $0.10597 * *$ & $0.132318 * *$ \\
\hline Ytd Total Return ${ }_{i, t-1}$ & -0.00025 & $-0.000572 *$ \\
\hline$M T B_{i, t-1}$ & $1.74 \mathrm{E} 06 * *$ & $1.95 \mathrm{E}-06^{* *}$ \\
\hline$R_{t-1}^{\text {Firm }}$ & $-5.13 \mathrm{E}-06$ & $-5.6 \mathrm{E}-06 * *$ \\
\hline$R_{t-1}^{M a c r o}$ & -0.00130 & -0.022178 \\
\hline$R_{t-1}^{\text {Market }}$ & $0.05883^{*}$ & 0.02755 \\
\hline$R_{t-1}^{\text {Pol }}$ & -0.0187 & -0.017815 \\
\hline Adjusted R-squared & 0.897805 & 0.889607 \\
\hline Akaike inf criterion & -1.0658 & -1.1252 \\
\hline Schwarz inf criterion & -0.4073 & -1.114 \\
\hline Hannan-Quinn criter. & -0.8091 & -1.1214 \\
\hline
\end{tabular}

$* *$ denotes significant at $1 \%$ and $*$ denotes significant at $5 \% *$.

We report a negative impact of asset tangibility on target leverage which implies a weak support for the signaling theory. This result is in the line with those of Sheikh and Wang (2011) with assumption that higher asset tangibility involves higher operating risk. Moreover, it consistent with results of Sakr and Bedeir (2019) using Egyptian sample. However, it contradicts with those of Dufour, et. al, (2018), Kythreotis, et. al, (2018), Aderajew, et, al. (2018), El-Habashy (2018). The negative impact business risk on leverage is agreed with results of Kythreotis, et. al, (2018), Aderajew, et. al, (2018) and Sakr and Bedeir (2019) supports theory of pecking order and the Trade-off theory. This reveals that the increased volatility of sales revenues decreases ability to repay debts and consequently firms are less willing to borrow more debts. The two years total returns are negatively impacting target leverage supports the prediction of the market timing theory that firms react to increase in market share price by issuing equity and thereby reducing leverage ratio. Stock market volatility, Macroeconomic risk, political risk, profitability, and size are not statistically significant. This implies that when managers consider the risk factors in targeting the leverage ratio, their demand for debt is significantly affected by the firm (business) risk more than any other risk factors. Thus, hypotheses (H4, H6, H7, H8 and H9) are rejected.

Table 8. Adjustment speed for the risk factors model

\begin{tabular}{ccc}
\hline Dependent Variable: $\mathrm{L}_{i, t}-L_{i, t-1}$ & & \\
\hline Variable & coefficient & Sig. \\
\hline$L_{i, t}^{T}-L_{i, t-1}$ & 0.228949 & 0.000 \\
\hline
\end{tabular}


It is observant in table 8 that the adjustment coefficient is positively statistically significant and equals $22.89 \%$ which indicates that the cost of deviating from the target is higher than the cost of adjustment. This indicates that Egyptian listed firms close about $22.9 \%$ of the gap between the current and target leverage in one year, that is, they take 4.36 years to move to the target leverage. Obviously, in the presence of risk factors, Egyptian listed firms adjust their current capital structure slower to the target structure. Collectively, managers of Egyptian firms take 4.36 years to adjust the current leverage towards the target leverage in response of the changes in MTB ratio, business risk, Asset tangibility, 2 YTD Total Return, investment, non-debt tax shield factors.

\section{Discussion and Conclusion}

This paper seeks to identify the determinants of and adjustment speed to the target capital structure using a panel of Egyptian Listed firms over the period of 2009 - 2018. We argue that firms respond differently to the growth factors and the risk factors in designing their target capital structure. In turn, we develop two models: one for growth factors and one for risk factors to examine the determinants of target leverage for Egyptian listed firms. Subsequently, we measure the adjustment speed for each model to estimate the time the firms take to adjust their current leverage to reach the target leverage.

In the growth factors model, political risk, profitability, and stock market return are negatively affect the target leverage of Egyptian firms. In contrast, MTB ratio, non-debt tax shield, size have significant positive effects on the target leverage. However, economic growth, firm growth, stock return and asset Tangibility have no significant impact on the target leverage. The findings reveal that managers of Egyptian firms tend to raise debts when investor sentiment is high and have large non-debt tax shield, low cost of asymmetric information, insufficient internal funds and with low political uncertainty.

In the presence of the risk factors (including firm-specific risk, stock market volatility, macroeconomic risk), the political risk, size and profitability lose their significant effect for the account of investment, firm risk, stock return and asset tangibility. Interestingly, both MTB ratio and non-debt tax shield preserve their positive effect. Macroeconomic risk and stock market volatility have no significant effect. However, the firm-specific risk (measured by volatility of sales growth) is the most important risk determinant of the target leverage.

Regarding the adjustment speed, we report different magnitudes of adjustment speed towards the target leverage between the growth factors and risk factors affecting the target leverage. Considering the growth factors, Egyptian firms could cover $36.5 \%$ of the gap between the current and target leverage, indicating they take 2.74 years to reach the target leverage. In the presence of risk factors, the Egyptian firm could cover $22.9 \%$ of the gap between the current and the target leverage, indicating that they take 4.36 years to move towards the target leverage. Thus, the firm adjust faster in case of considering the growth factors than if they consider the risk factors.

Scope of this paper is limited to examine empirically determinants of the target leverage and to calculate the adjustment speed of capital structure towards the target leverage and does not extend to examine the firm specific and macroeconomic determinants of the adjustment speed. Thus, further research can be extended to investigate the determinants of adjustment speed. Moreover, we select the most used firm-specific variables in the literature, and it is difficult in an empirical study to use all variables. Therefore, variables such as ownership structure, taxes, interest rate, inflation, unemployment may be having significant effect and could be tested in further research.

\section{References}

Aderajew, T. S., Trujillo-Barrera, A., \& Pennings, J. M. E. (2019). Dynamic target capital structure and speed of adjustment in farm business. European Review of Agricultural Economics, 46(4), 637-661. https://doi.org/10.1093/erae/jby035

Agarwal, S., \& Mohtadi, H. (2004). Financial markets and the financing choice of firms: Evidence from developing countries. Global Finance Journal, 15(1), 57-70. https://doi.org/10.1016/j.gfj.2003.10.004

Ahmed Sheikh, N., \& Wang, Z. (2011). Determinants of capital structure: An empirical study of firms in manufacturing industry of Pakistan. Managerial Finance, 37(2), 117-133. https://doi.org/10.1108/03074351111103668

Ahmed, Z., \& Hla, D. T. (2019). Stock return volatility and capital structure measures of nonfinancial firms in a dynamic panel model: Evidence from Pakistan. International Journal of Finance and Economics, 24(1), 604-628. https://doi.org/10.1002/ijfe.1682 
Ahsan, T., Wang, M., \& Qureshi, M. A. (2016). Firm, industry, and country level determinants of capital structure: evidence from Pakistan. South Asian Journal of Global Business Research, 5(3), 362-384. https://doi.org/10.1108/sajgbr-05-2015-0036

Alber, N., \& Iman, Y. (2020). Capital Structure Determinants: A Cross-Country Analysis. International Business Research, 13(5), 95-112. https://doi.org/10.5539/ibr.v13n5p95

Amelot, L. M. M., Ushad, S. A., \& Lamport, M. (2018). Capital Structure and Political Risk in an Emerging Market: Evidence from Companies Listed on the Stock Exchange of Mauritius. Business and Economic Research, 8(3), 104. https://doi.org/10.5296/ber.v8i3.13367

Arena, M. P., \& Roper, A. H. (2010). The effect of taxes on multinational debt location. Journal of Corporate Finance, 16(5), 637-654. https://doi.org/10.1016/j.jcorpfin.2010.07.006

Aybar-Arias, C., Casino-Martínez, A., \& López-Gracia, J. (2012). On the adjustment speed of SMEs to their optimal capital structure. Small Business Economics, 39(4), 977-996. https://doi.org/10.1007/s11187-011-9327-6

Baker, M., \& Wurgler, J. (n.d.). Market Timing and Capital Structure.

Barry, P. J., Bierlen, R. W., \& Sotomayor, N. L. (2000). Financial Structure of Farm Businesses Under Imperfect Capital Markets. Amer. J. Agr. Econ., 82.

Baum, C. F., Caglayan, M., \& Rashid, A. (2017). Capital structure adjustments: Do macroeconomic and business risks matter?. Empirical Economics, 53(4), 1463-1502. https://doi.org/10.1007/s00181-016-1178-1

Belkhir, M., Maghyereh, A., \& Awartani, B. (2016). Institutions and corporate capital structure in the MENA region. Emerging Markets Review, 26, 99-129. https://doi.org/10.1016/j.ememar.2016.01.001

Benavente, J. M., Johnson, C. A., \& Morandé, F. G. (2003). Debt composition and balance sheet effects of exchange rate depreciations: A firm-level analysis for Chile. Emerging Markets Review, 4(4), 397-416. https://doi.org/10.1016/S1566-0141(03)00062-1

Bhattacharjee, A., \& Han, J. (2014). Financial distress of Chinese firms: Microeconomic, macroeconomic and institutional influences. China Economic Review, 30, 244-262. https://doi.org/10.1016/j.chieco.2014.07.007

Bokpin, G. A. (2010). Financial market development and corporate financing: Evidence from emerging market economies. Journal of Economic Studies, 37(1), 96-116. https://doi.org/10.1108/01443581011012270

Brei, M., \& Charpe, M. (2012). Currency depreciations, financial transfers, and firm heterogeneity. Emerging Markets Review, 13(1), 26-41. https://doi.org/10.1016/j.ememar.2011.09.003

Burgman, T. A. (1996). An Empirical Examination of Multinational Corporate Capital Structure. Journal of International Business Studies, 27.

Cashman, G. D., Harrison, D. M., \& Seiler, M. J. (2016). Capital Structure and Political Risk in Asia-Pacific Real Estate Markets. Journal of Real Estate Finance and Economics, 53(2), 115-140. https://doi.org/10.1007/s11146-013-9436-x

Cashman, G. D., Harrison, D. M., \& Sheng, H. (2015). Political Risk and Cost of Capital 331. International Real Estate Review, 18.

Chan, C. C., \& Chang, Y. H. (2008). Firm-specific stock return variation and capital structure decisions. Applied Economics Letters, 15(4), 293-299. https://doi.org/10.1080/13504850500426244

Chow, Y. P., Muhammad, J., Bany-Ariffin, A. N., \& Cheng, F. F. (2018). Macroeconomic uncertainty, corporate governance and corporate capital structure. International Journal of Managerial Finance, 14(3), 301-321. https://doi.org/10.1108/IJMF-08-2017-0156

Dang, V. A., Kim, M., \& Shin, Y. (2012). Asymmetric capital structure adjustments: New evidence from dynamic panel threshold models. Journal of Empirical Finance, 19(4), 465-482. https://doi.org/10.1016/j.jempfin.2012.04.004

Demirgii-Kunt, A., \& Maksimovic, V. (1996). Stock Market Development and Financing Choices of Firms.

Devos, E., Rahman, S., \& Tsang, D. (2017). Debt covenants and the speed of capital structure adjustment. Journal of Corporate Finance, 45, 1-18. https://doi.org/10.1016/j.jcorpfin.2017.04.008 
Drobetz, W., Schilling, D. C., \& Schröder, H. (2015). Heterogeneity in the Speed of Capital Structure Adjustment across Countries and over the Business Cycle. European Financial Management, 21(5), 936-973. https://doi.org/10.1111/eufm.12048

Dufour, D., Luu, P., \& Teller, P. (2018). The influence of cash flow on the speed of adjustment to the optimal capital structure. Research in International Business and Finance, 45, 62-71. https://doi.org/10.1016/j.ribaf.2017.07.132

El-Habashy, H. A. (2018). Determinants of Capital Structure within the Context of Corporate Governance in Egypt. International Journal of Business and Management, 13(8), 26. https://doi.org/10.5539/ijbm.v13n8p26

Fama, E. F., \& French, K. R. (2002). Testing Trade-Off and Pecking Order Predictions About Dividends and Debt. The Review of Financial Studies Spring, 15.

Faulkender, M., Flannery, M. J., Hankins, K. W., \& Smith, J. M. (2012). Cash flows and leverage adjustments. Journal of Financial Economics, 103(3), 632-646. https://doi.org/10.1016/j.jfineco.2011.10.013

Featherstone, A. M., Ibendahl, G. A., Winter, J. R., \& Spaulding, A. (2005). Farm financial structure. Agricultural Finance Review, 65(2), 97-117. https://doi.org/10.1108/00214660580001163

Fischer, E. O., Heinkel, R., \& Zechner, J. (1989). American Finance Association Dynamic Capital Structure Choice: Theory and Tests. The Journal of Finance, 44.

Flannery, M. J., \& Hankins, K. W. (2013). Estimating dynamic panel models in corporate finance. Journal of Corporate Finance, 19(1), 1-19. https://doi.org/10.1016/j.jcorpfin.2012.09.004

Flannery, M. J., \& Rangan, K. P. (2006). Partial adjustment toward target capital structures. Journal of Financial Economics, 79(3), 469-506. https://doi.org/10.1016/j.jfineco.2005.03.004

Frank, M. Z., \& Goyal, V. K. (2004). The effect of market conditions on capital structure adjustment. Finance Research Letters, 1(1), 47-55. https://doi.org/10.1016/S1544-6123(03)00005-9

Frank, M. Z., Goyal, V. K., Barclay, M., Christie, B., Dasgupta, S., Graham, J., .. Wurgler, J. (2009). Capital Structure Decisions: Which Factors Are Reliably Important?. Financial Management $\bullet$ Spring.

Ghose, B. (2017). Impact of Business Group Affiliation on Capital Structure Adjustment Speed: Evidence from Indian Manufacturing Sector. Emerging Economy Studies, 3(1), 54-67. https://doi.org/10.1177/2394901517696605

Giombini, G., Teobaldelli, D., \& Schneider, F. (2018, December). Interaction effect of tax evasion and legal system inefficiency on firms' financial constraints. International Review of Economics and Finance, 55, 1-20. https://doi.org/10.1016/j.iref.2018.01.009

Graham, J. R., Leary, M. T., \& Roberts, M. R. (2015). A century of capital structure: The leveraging of corporate America. Journal of Financial Economics, 118(3), 658-683. https://doi.org/10.1016/j.jfineco.2014.08.005

Groh, A. P., \& Wallmeroth, J. (2016). Determinants of venture capital investments in emerging markets. Emerging Markets Review, 29, 104-132. https://doi.org/10.1016/j.ememar.2016.08.020

Hasan, I., \& Hunter, W. C. (2000). Research in Banking and Finance. JAI.

Hovakimian, A., Hovakimian, G., \& Tehranian, H. (2004). Determinants of target capital structure: The case of dual debt and equity issues. Journal of Financial Economics, 71(3), 517-540. https://doi.org/10.1016/S0304-405X(03)00181-8

Huttel, S., Mußhoff, O., \& Odening, M. (2010). Investment reluctance: Irreversibility or imperfect capital markets?. European Review of Agricultural Economics, 37(1), 51-76. https://doi.org/10.1093/erae/jbp046

Jackson, S. B., Keune, T. M., \& Salzsieder, L. (2013). Debt, equity, and capital investment. Journal of Accounting and Economics, 56(2-3), 291-310. https://doi.org/10.1016/j.jacceco.2013.09.001

Jensen, M. C., Donaldson, G., Jacobs, A., Light, J., Smith, C., Weinhold, W., ... Ruback, R. (n.d.). Agency Costs of Free Cash Flow. Corporate Finance, and Takeovers.

Karpavičius, S., \& Yu, F. (2017). The impact of interest rates on firms' financing policies. Journal of Corporate Finance, 45, 262-293. https://doi.org/10.1016/j.jcorpfin.2017.05.007

Kayhan, A., \& Titman, S. (2007). Firms' histories and their capital structures. Journal of Financial Economics, 83(1), 1-32. https://doi.org/10.1016/j.jfineco.2005.10.007

Kelly, P. J., \& Carey, W. P. (n.d.). Real and Inflationary Macroeconomic Risk in the Fama and French Size and Book-to-Market Portfolios. 
Kent Baker, H., \& Kilincarslan, E. (2019, October). Why companies do not pay cash dividends: The Turkish experience. Global Finance Journal, 42. https://doi.org/10.1016/j.gfj.2018.02.005

Kim, H. J., Sohn, P., \& Seo, J.-Y. (n.d.). The capital structure adjustment through debt nancing based on various macroeconomic conditions in Korean market*. Investigación Económica, LXXIV.

Kythreotis, A., Nouri, B. A., \& Soltani, M. (2017). Determinants of Capital Structure and Speed of Adjustment: Evidence from Iran and Australia. International Journal of Business Administration, 9(1), 88. https://doi.org/10.5430/ijba.v9n1p88

Lemma, T. T., \& Negash, M. (2014). Determinants of the adjustment speed of capital structure: Evidence from developing economies. Journal of Applied Accounting Research, 15(1), 64-99. https://doi.org/10.1108/JAAR-03-2012-0023

Li, N., Richardson, S., \& Tuna, I. (2014). Macro to micro: Country exposures, firm fundamentals and stock returns. Journal of Accounting and Economics, 58(1), 1-20. https://doi.org/10.1016/j.jacceco.2014.04.005

Mai, Y., Meng, L., \& Ye, Z. (2017). Regional variation in the capital structure adjustment speed of listed firms: Evidence from China. Economic Modelling, 64, 288-294. https://doi.org/10.1016/j.econmod.2017.03.028

Miller, M. H. (1977). DEBT AND TAXES. The Journal of Finance, 32(2), 261-275. https://doi.org/10.1111/j.1540-6261.1977.tb03267.x

Minh Tai, L., Lo, C., \& Chi Minh City, H. (2017). International Journal of Economics and Financial Issues Impact of the Financial Markets Development on Capital Structure of Firms Listed on Ho Chi Minh Stock Exchange. International Journal of Economics and Financial Issues, 7(3), 510. Retrieved from http:www.econjournals.com

Mokhova, N., \& Zinecker, M. (2014). Macroeconomic Factors and Corporate Capital Structure. Procedia - Social and Behavioral Sciences, 110, 530-540. https://doi.org/10.1016/j.sbspro.2013.12.897

Myers, S. C., \& Majluf, N. S. (1984). Corporate Financing and Investment Decisions When Firms Have Information That Investors Do Not Have*. Journal of Financial Economics, 13.

Pan, W. F., Wang, X., \& Yang, S. (2019). Debt maturity, leverage, and political uncertainty. North American Journal of Economics and Finance, 50. https://doi.org/10.1016/j.najef.2019.04.024

Pindado, J., Requejo, I., \& Rivera, J. C. (2017, July). Economic forecast and corporate leverage choices: The role of the institutional environment. International Review of Economics and Finance, 51, 121-144. https://doi.org/10.1016/j.iref.2017.05.006

Rajan, R. G., \& Zingales, L. (1995). American Finance Association What Do We Know about Capital Structure? Some Evidence from International Data. The Journal of Finance, 50.

Rashid, A. (2014). Firm external financing decisions: explaining the role of risks. Managerial Finance, 40(1), 97-116. https://doi.org/10.1108/MF-02-2013-0049

Ross, S. A. (n.d.). The Determination of Financial Structure: The Incentive-Signalling Approach. The Bell Journal of Economics, 8.

Sakr, A., \& Bedeir, A. (2019). Firm level determinants of capital structure: Evidence from Egypt. International Journal of Financial Research, 10(1), 68-87. https://doi.org/10.5430/ijfr.v10n1p68

Schwert, G. W. (1989). Why Does Stock Market Volatility Change Over Time?. The Journal of Finance, 44(5), 1115-1153. https://doi.org/10.1111/j.15406261.1989.tb02647.x

Sherif, M. (2015). Market timing behaviour, bankruptcy costs and capital structure decisions in MENA: the case of Egypt. Int. J. Accounting, Auditing and Performance Evaluation, 11.

Shibata, T., \& Nishihara, M. (2018). Investment timing, reversibility, and financing constraints. Journal of Corporate Finance, 48, 771-796. https://doi.org/10.1016/j.jcorpfin.2017.12.024

Soekarno, S., Kitri, M. L., \& Utomo, S. (2016). Capital structure determinants and the speed of adjustment towards capital structure target: evidence from Indonesian state-owned enterprises. Int. J. Monetary Economics and Finance, 9.

Titman, S., \& Wessels, R. (2007). The determinants of capital Structure Choice. The Journal of Finance, 43(1), 1-19.

Wang, X., Xu, W., \& Zhong, Z. (Ken). (2019). Economic policy uncertainty, CDS spreads, and CDS liquidity provision. Journal of Futures Markets, 39(4), 461-480. https://doi.org/10.1002/fut.21982 
Won Seo, S., \& Jin Chung, H. (2017). Capital structure and corporate reaction to negative stock return shocks. International Review of Economics and Finance, 49, 292-312. https://doi.org/10.1016/j.iref.2017.02.005

Yang, B. (2013). Dynamic capital structure with heterogeneous beliefs and market timing. Journal of Corporate Finance, 22(1), 254-277. https://doi.org/10.1016/j.jcorpfin.2013.05.003

Youssef, A., \& El-ghonamie, A. (2015). Factors That Determine Capital Structure in Building Material and Construction Listed Firms: Egypt Case. International Journal of Financial Research, 6(4). https://doi.org/10.5430/ijfr.v6n4p46

Zhao, J., Barry, P. J., \& Katchova, A. L. (n.d.). Signaling Credit Risk in Agriculture: Implications for Capital Structure Analysis.

\section{Notes}

Note 1. Target leverage (capital structure) is defined as weights of debts and equity targeted to maximize firm value.

Note 2. Baum, Caglayan, \& Rashid (2016) suggest that models without risk factors yield biased results.

Note 3. However, Titman and Wessels (1988) and Fischer, et. al, (1989) show that transaction costs are important determinants of a capital structure decision.

\section{Copyrights}

Copyright for this article is retained by the author(s), with first publication rights granted to the journal.

This is an open-access article distributed under the terms and conditions of the Creative Commons Attribution license (http://creativecommons.org/licenses/by/4.0/). 